\title{
СТУПІНЬ РОЗРОБЛЕННЯ ПРОБЛЕМИ КРИМІНАЛЬНОЇ ВІДПОВІДАЛЬНОСТІ ЗА ПІДКУП СЛУЖБОВОЇ ОСОБИ ЮРИДИЧНОЇ ОСОБИ ПРИВАТНОГО ПРАВА НЕЗАЛЕЖНО ВІД ОРГАНІЗАЦІЙНО-ПРАВОВОЇ ФОРМИ
}

Троченко О. В.

Темою статmі є ступінь розробки проблеми кримінальної відповідальності за підкуп службової особи юридичної особи приватного права незалежно від організаційно-правової форми. У результаті виконаної роботи отримано певні науково-теоретичні результати, які мають значення не лише для науки, а й для діяльності правозастосовних органів і вдосконалення відповідних положень чинного кримінального законодавства України. У процесі дослідження здійснено аналіз ступінь розробки проблеми кримінальної відповідальності за підкуп службової особи юридичної особи приватного права незалежно від організаційно-правової форми. Проаналізовано особливості проблематики кримінальної відповідальності за корупційні злочини.

Прагнення України до євроінтеграції сприяло усвідомленню потреби в перегляді певних положень кримінального законодавства, зокрема щодо запобігання i протидії корупції, узгодження його з міжнародним стандартами. Отже, для встановлення напрямів боротьби з корупцією наша держава ратифікувала низку міжнародно-правових актів та дотрималась рекомендацій міжнародних організацій (Групи держав nроти корупції (GRECO), Організації економічної сnівnраці та розвитку (ОЕСР та ін.). У зв'язку з імплементацією стандартів базових антикорупційних конвенцій у кримінальне законодавство України поняття «хабар» було замінено на юридичну конструкцію «неправомірна вигода». Відповідно, основною новелою у цьому стала диференціація кримінальної відповідальності за спеціальним суб'єктом, а також встановлення кримінальної відповідальності не лише за одержання особою неправомірної вигоди, а й за прийняття нею пропозиції чи обіцянки, які визнаються закінченими вже на початок виконання суспільно небезпечного діяння.

Викладені в роботі висновки та пропозиції мають i теоретичне, і прикладне значення. Отже, наведені положення можуть бути використані для подальшого вдосконалення кримінального законодавства України в частині кримінальної відповідальності за підкуп службової особи юридичної особи приватного права незалежно від організаційно-правової форми. Викладені в роботі висновки та пропозиції можуть бути застосовані у рамках вивчення Особливої частини кримінального права України, підготовки відповідних навчальних посібників, підручників, науково-практичних коментарів. Викладені пропозиції можуть слугувати додатковим науковим матеріалом для подальшого виконання правових досліджень, які стосуються питань кримінальної відповідальності за підкуп службової особи юридичної особи приватного права незалежно від організаційно-правової форми.

Здійснено огляд історії вітчизняного кримінального законодавства, зокрема злочинів, які полягають у підкупі службової особи юридичної особи приватного права незалежно від організаційно-правової форми.

Ключові слова: службова особа, підкуп, організаційно-правова форма, відповідальність, злочин, корупція.

Trotsenko $0 . \quad$ V. Degree of development of the problem of criminal responsibility for bribery of official of a legal entity of private law regardless of the organizational and legal form

The topic of the article is the degree of elaboration of the problem of criminal liability for bribery of an official of a legal entity of private law, regardless of the organizational and legal form. As a result of this work, certain scientific and theoretical results were obtained, which are important not only for science but also for the activities of law enforcement agencies, as well as to improve the relevant provisions of current criminal law of Ukraine. In the course of the research the degree of elaboration of the problem of criminal liability for bribery of an official of a legal entity of private law, regardless of the organizational and legal form, was analyzed. Peculiarities of criminal liability for corruption crimes are analyzed.

Ukraine's desire for European integration has contributed to the awareness of the need to revise certain provisions of criminal law, in particular, to prevent and combat corruption, to bring it into line with international standards. Therefore, in order to establish the directions of the fight against corruption, our state has ratified a number of international legal acts and complied with 
the recommendations of international organizations (Group of States against Corruption (GRECO), Organization for Economic Cooperation and Development (OECD, etc.). Due to the implementation of the standards of basic anti-corruption conventions in the criminal legislation of Ukraine, the concept of "bribe" was replaced by the legal construction of "illegal gain". Accordingly, the main novelty in this was the differentiation of criminal liability for a special entity, as well as the establishment of criminal liability not only for obtaining illegal benefits, but also for accepting his proposal or promise, which is considered complete at the beginning of a socially dangerous act.

The conclusions and proposals presented in the paper have both theoretical and applied significance. Therefore, the provisions presented in the dissertation can be used to further improve the criminal legislation of Ukraine in terms of criminal liability for bribery of an official of a legal entity of private law, regardless of organizational and legal form. The conclusions and proposals set out in the paper can be used in the study of the Special Part of the criminal law of Ukraine, the preparation of relevant textbooks, textbooks, scientific and practical comments. The above proposals can serve as additional scientific material for further legal research related to criminal liability for bribery of an official of a legal entity of private law, regardless of organizational and legal form.

$A$ review of the history of domestic criminal law, in particular crimes involving the bribery of an official of a legal entity of private law, regardless of organizational and legal form.

Key words: public servants, bribe, legal form, responsibility, crime, corruption.

Постановка проблеми та їі актуальність. Вступивши на євроінтеграційний шлях, наша держава поклала на себе низку зобов'язань, серед яких узгодити Кримінальний кодекс України з міжнародними стандартами та acquiscommunautaire. Значний вплив на формування антикорупційного законодавства України мала Конвенція ООН проти корупції від 31 жовтня 2003 р., у ст. 21 якої міститься рекомендація криміналізувати підкуп у приватному секторі. Якщо провести порівняльний аналіз положень кримінального законодавства зарубіжних країн, можна встановити, що суб'єктом підкупу в приватному секторі $\epsilon$ не будь-яка особа, яка діє в цьому секторі, а лише та особа, яка, не перебуваючи на публічній службі, представляє інтереси іншої особи та, вчиняючи підкуп, порушує умови співробітництва зі своїм довірителем (наприклад, роботодавцем).

Аналіз останніх досліджень і публікацій. Проблеми притягнення до кримінальної відповідальності за вчинення службових злочинів у різні часи ставали предметом дослідження видатних, як вітчизняних, так і зарубіжних вчених. Не можна не виділити вагомий внесок таких науковців, як П.П. Андрушко, О.Я. Асніс, Л.П. Брич, В.М. Бурдін, Б.В. Волженкін, Д.М. Горбачов, О.М. Грудзур, Н.О. Єгорова, З.А. Загиней, К.П. Задоя, Г.М. Зеленов, С.В. Ізосімов, О.О. Кваша, А.К. Квіцинія, В.М. Киричко, М.Й. Коржанський, Д.І. Крупко, В.М. Куц, Р.Л. Максимович, М.І. Мельник, В.А. Мисливий, В.О. Навроцький, А.В. Савченко, О.Я. Свєтлов, Т.І. Слуцька, А.А. Стрижевська, В.І. Тютюгін, П.Л. Фріс, М.І. Хавронюк, А.В. Шнітенков, П.С. Яні, Н.М. Ярмиш та інші.

Однак, віддаючи належне напрацюванням вказаних науковців, варто зазначити, що у вітчизняній кримінально-правовій науці комплексних досліджень питань кримінальної відповідальності за підкуп службової особи юридичної особи приватного права практично немає. Лише окремі представники київської та львівської правових шкіл докладно розглядали певні проблемні аспекти корупційних злочинів, у контексті яких було частково висвітлено i проблематику правильного розуміння та практичного застосування ст. 368-3 КК України. Актуальності цій темі додає та обставина, що на підставі Закону України від 13 травня 2014 р. «Про внесення змін до деяких законодавчих актів України у сфері державної антикорупційної політики у зв'язку з виконанням Плану дій щодо лібералізації Європейським Союзом візового режиму для України» ст. 368-3 КК України було викладено у новій редакції.

Внаслідок постійного оновлення вітчизняне антикорупційне законодавство стає дедалі більш заплутаним і складним для сприйняття. Потребують висвітлення дискусійні аспекти кримінально-правової характеристики (розуміння неправомірної вигоди, обґрунтованість виокремлення пропозиції, обіцянки та прохання неправомірної вигоди, визначення поняття «службова особа юридичної особи приватного права незалежно від організаційно-правової форми», наявність вимагання неправомірної вигоди в разі реалізації дискреційних повноважень тощо), а також з'ясування питання, наскільки вдалим для втілення ідеї диференціації кримінальної відповідальності за службові правопорушення різних управлінців $\epsilon$ вибраний законодавцем критерій, а саме: поділ юридичних осіб на два види - публічного і приватного права. Саме на ці питання спробувала відповісти Я.В. Ризак у своїй дисертаційній роботі «Кримінальна відповідальність за підкуп службової особи юридичної особи приватного 

та науково-методичне забезпечення

права» [1, с. 180]. 3 плином часу вона не втратила своєї актуальності, однак так і залишилася однією з небагатьох.

Метою статті $\epsilon$ аналіз ступеня розробки проблеми кримінальної відповідальності за підкуп службової особи юридичної особи приватного права незалежно від організаційно-правової форми, особливостей проблематики кримінальної відповідальності за корупційні злочини.

Виклад основного матеріалу. До найбільш важливих положень, які варто виділити у вказаній вище роботі, варто зарахувати такі:

пропозиція узгодити чинне антикорупційне законодавство України з офіційним перекладом Конвенції ООН проти корупції, замінивши в ньому термін «неправомірна перевага» терміном «неправомірна вигода» (що й було зроблено вже в редакції Закону № 222-VII від 18.04.2013 р.);

3 метою більш послідовної реалізації ідеї диференціації кримінальної відповідальності за службові правопорушення в публічній і приватній сферах, усунення неузгодженості між назвою ст. 368-3 КК України і диспозиціями цієї статті, а також уточнення поведінки одержувача неправомірної вигоди запропоновано в ч. 1 іч. 3 ст. 368-3 КК України вказати на зумовленість діянь службової особи, в ч. 3 ст. 368-3 КК України зворот «із використанням наданих їй повноважень» замінити словосполученням «із використанням їі службового становища або зумовлених ним можливостей», уточнити назву ст. 368-3 КК України з урахуванням етимології слова «підкуп»;

- обґрунтування необхідності розширити коло осіб, спроможних нести кримінальну відповідальність за одержання неправомірної вигоди в приватному секторі, за рахунок працівників фізичної особи - підприємця, які виконують організаційно-розпорядчі або адміністративно-господарські функції; позначити суб'єкт злочину, передбаченого ч. 3 ст. 368-3 КК України, як «службову особу, крім тієї, що вказана в ч. 1 примітки до ст. 364 КК України»; виключити з назв і диспозицій ст. 364-1 і ст. 368-3 КК України словосполучення «незалежно від організаційно-правової форми».

Виділені мною положення зазнали подальшого розвитку, а саме:

положення про обґрунтованість здійсненої в КК України заміни терміна «хабар» терміном «неправомірна вигода», визнання останньою немайнових благ і необхідність уточнення законодавчого визначення поняття неправомірної вигоди як предмета досліджуваного злочину;
- положення про слушність законодавчого виокремлення пропозиції неправомірної вигоди як злочинного діяння, недоречність такого рішення стосовно обіцянки неправомірної вигоди і помилковість встановлення кримінальної відповідальності за прохання надати неправомірну вигоду в ч. 1 ст. 368-3 КК України (доволі спірна думка авторки, з якою, без сумніву, можна погодитися в частині слушності виокремлення пропозиції неправомірної вигоди як злочинного діяння та помилковості встановлення кримінальної відповідальності за прохання надати неправомірну вигоду у ч. 1 статті. Тоді як, на нашу суб'єктивну думку, що не претендує на істину в останній інстанції, виокремлення обіцянки неправомірної вигоди як злочинного діяння $\epsilon$ доволі обґрунтованим, доречним і зумовленим об'єктивною реальністю, діяльністю практичних працівників, які зобов' язані у своїх діях суворо дотримуватись букви закону. Адже таке законодавче уточнення дозволяє з більшою впевненістю в можливості доведення розпочатого кримінального провадження до його логічного завершення переданням обвинувального акта до суду та притягненням винної особи до передбаченої законом відповідальності збирати належні, допустимі, достовірні та достатні докази винуватості осіб. Оскільки кожна особа має бути притягнута до відповідальності залежно від ступеню та характеру вини, обіцянка неправомірної вигоди як наступна, більш деталізована та реальна сходинка злочинної діяльності після пропозиції неправомірної вигоди має тягнути за собою і більш сувору міру покарання);

- положення про можливість визнання фізичної особи - підприємця службовою особою суб'єктом окремих злочинів у сфері службової діяльності, помилковість зарахування арбітражного керуючого до осіб, які здійснюють професійну діяльність, пов'язану з наданням публічних послуг, і безпідставність поширення дії вдосконаленої ст. 354 КК України на працівників юридичних осіб приватного права;

положення про необхідність уточнення законодавчого визначення поняття вимагання неправомірної вигоди, наявність цієї кваліфікуючої ознаки у разі використання службовою особою юридичної особи приватного права дискреційних повноважень і безпідставність виокремлення вимагання неправомірної вигоди як окремого прояву корупційної поведінки (щодо цього положення необхідні певні пояснення, а саме: в процесі імплементації у КК України положень між- 
народних конвенцій наш законодавець, на думку M.І. Бакай, не врахував, зокрема, «необхідність криміналізації вимагання хабаря та неправомірної вигоди як окремих («автономних») проявів корупційної поведінки (стосується положень, передбачених ч. 3 ст. 368, ч. 4 ст. 368-3, ч. 4 ст. 368-4 КК)» [2]. На думку 0.О. Дудорова, вести мову у цьому разі саме «про криміналізацію недоречно, адже вказана М.І. Бакай корупційна поведінка і на сьогодні вважається злочинною. Так, поведінка, яка розцінюється як вимагання неправомірної вигоди, поряд із власне одержанням такої вигоди за дії (бездіяльність) із використанням службових повноважень, входить до об'єктивної сторони кваліфікованого складу злочину - одержання неправомірної вигоди службовою особою юридичної особи приватного права, поєднаного з вимаганням» [1, с. 181]. Відповідно, вимагання неправомірної вигоди, отримати яку службовій особі юридичної особи приватного права не вдалося з незалежних від їі волі причин, має визнаватись замахом і кваліфікуватися за ч. 2 (ч. 3) ст. 15, ч. 4 ст. 368-3 КК України;

положення про залежність формування кримінально-правових заборон, розрахованих на зловживання службових осіб приватного сектора, від соціально-економічного розвитку суспільства і про узгодженість виділення цих заборон із таким принципом криміналізації, як міжнародно-правова необхідність і допустимість;

висновок про необхідність удосконалення кримінально-правового заохочення осіб, які пропонують або надають неправомірну вигоду.

B.I. Осадчий вважає за необхідне зауважити, що в ст.ст. 368, 368-3, 368-4, 369 Розділу XVII КК України «Злочини у сфері службової діяльності та професійної діяльності, пов'язаної з наданням публічних послуг» законодавець не дотримується єдиного узгодженого підходу до викладення кримінально-правових заборон [3, с. 367-402]. У ст. 368 КК України «Прийняття пропозиції, обіцянки або одержання неправомірної вигоди службовою особою» відповідальність встановлена за прийняття пропозицію, обіцянку або одержання службовою особою неправомірної вигоди, а також прохання надати таку вигоду для себе чи третьої особи за вчинення чи невчинення такою службовою особою в інтересах того, хто пропонує, обіцяє чи надає неправомірну вигоду, чи в інтересах третьої особи будь-якої дії з використанням наданої їй влади чи службового становища. Тоді як ст. 369 КК України «Пропозиція, обіцянка або надання неправомірної вигоди служ- бовій особі» передбачено відповідальність за пропозицію чи обіцянку службовій особі надати їй або третій особі неправомірну вигоду, а також надання такої вигоди за вчинення чи невчинення службовою особою в інтересах того, хто пропонує, обіцяє чи надає таку вигоду, чи в інтересах третьої особи будь-якої дії з використанням наданої їй влади чи службового становища. Тобто у ст. 368 КК України встановлено відповідальність лише особи, яка приймає пропозицію, обіцянку або одержує неправомірну вигоду чи просить надати таку вигоду, а в ст. 369 КК України - відповідальність лише особи, яка пропонує, обіцяє надати неправомірну вигоду чи надає іiі. Відповідно до ст. 368-3 КК України «Підкуп службової особи юридичної особи приватного права незалежно від організаційно-правової форми», ст. 368-4 КК України «Підкуп особи, яка надає публічні послуги» відповідальність передбачена як особи, яка підкуповує, так і особи, яку підкуповують. Проте підкуп не охоплює прийняття пропозиції, обіцянки або одержання неправомірної вигоди, тому доцільно дотримуватись єдиного підходу в процесі формування кримінально-правових заборон [4, с. 146].

На жаль, це не єдиний недолік, який продовжує існувати у Кримінальному кодексі та, здається, тривожить лише представників наукових кіл. У чинному законодавчому визначенні вимагання неправомірної вигоди (п. 5 примітки до ст. 354 КК України) вказівка на законні інтереси особи фігурує лише стосовно завуальованої форми вимагання і відсутня стосовно відкритої форми вимагання. Саме цей факт наводить 0.0. Дудорова та Я.В. Ризак на думку про те, що це - «прикра законодавча помилка, а не усвідомлене рішення українських парламентаріїв, які сприйняли позицію окремих дослідників (О.Я. Свєтлов, П.С. Яні), згідно з якою одержання хабаря $є$ настільки небезпечним злочином, що вимогу передати його під погрозою вчинення будь-яких службових діянь (як законних, так і незаконних) необхідно визнавати вимаганням хабаря. За таких обставин п. 5 примітки до ст. 354 КК України варто уточнити, усунувши позначену непослідовність і чітко вказавши на те, що вимагання неправомірної вигоди має місце лише в разі вимоги щодо надання неправомірної вигоди з погрозою вчинення дій (бездіяльності), якщо це ставить у небезпеку законні інтереси того, в кого вимагають неправомірну вигоду» [1, с. 183]. Із визначення поняття «вимагання неправомірної вигоди», якщо тлумачити п. 5 примітки до ст. 354 КК України буквально, випливає, 
що особа, яка під впливом вимагання лише запропонувала або пообіцяла неправомірну вигоду, але ще іï не надала, не може вважатись такою, щодо якої було вчинене вимагання. Досить складно встановити, законні чи незаконні інтереси намагається реалізувати той, хто пропонує (надає) неправомірну вигоду, у ситуаціях, коли службова особа - одержувач неправомірної вигоди здійснює дискреційні повноваження. 3 цього приводу О.Я. Свєтлов писав: «Іноді взагалі неможливо визначити, якими діями (законними чи незаконними) погрожує особа, яка вимагає хабар. Для ілюстрації цієї думки вчений наводив приклад із двома особами, які претендують на роботу в організації за наявності лише однієї вакансії. Вибрати з двох осіб кращого кандидата - право керівника, який може вимагати хабар з обох претендентів, розраховуючи прийняти на роботу того, хто дасть йому (пообіцяє) більшу суму» [4, с. 156].

Згадані нами вище автори схильні стверджувати, що інтерес того, хто пропонує (надає) неправомірну вигоду, якщо погроза стосується вчинення діяння з використанням дискреційних повноважень службової особи юридичної особи приватного права, не суперечить чинному законодавству, а тому має визнаватись законним. Іншими словами, під законними інтересами у процесі вимагання неправомірної вигоди 0.0. Дудоров та Я.В. Ризак пропонують розуміти, у т.ч., інтереси, які не суперечать чинному законодавству і реалізація яких лише частково забезпечується нормативним регулюванням (залишається простір для індивідуального піднормативного регулювання у вигляді дій службової особи юридичної особи приватного права за власним розсудом) [1, с. 182]. Обґрунтованість наведеного підходу підтверджується Рішенням Конституційного Суду України від 1 грудня 2004 р. у справі за конституційним поданням 50 народних депутатів України щодо офіційного тлумачення окремих положень ч. 1 ст. 4 ЦПК України від 1 грудня 2004 р. № 18-рп/2004 [5, с. 15]. У згаданому Рішенні поняття «охоронюваний законом інтерес», що вживається в законах України і може вважатись тотожним поняттю «законний інтерес», характе- ризується як правовий феномен, який: 1) виходить за межі суб'єктивного права; 2) є самостійним об'єктом засобів правової охорони; 3) має на меті задоволення усвідомлених індивідуальних і колективних потреб; 4) не може суперечити Конституції і законам України, суспільним інтересам, загальновизнаним принципам права; 5) означає прагнення до користування в межах правового регулювання конкретним матеріальним або нематеріальним благом; 6) розглядається як простий легітимний дозвіл, тобто такий, що не заборонений законом.

Висновки. Отже, як бачимо, ступінь розробки проблеми кримінальної відповідальності за підкуп службової особи юридичної особи приватного права $€$ недосконалим, i, незважаючи на майже 5-річну історію існування у Кримінальному кодексі України ст. 368-3, залишається багато суперечливих та невирішених питань.

\section{Література}

1. Дудоров О.О., Ризак Я.В. Проблемні питання вимагання неправомірної вигоди при вчиненні підкупу службової особи юридичної особи приватного права. Вісник кримінального судочинства. 2015. № 1. C. 180-191. URL: http://nbuv.gov.ua/UJRN/ vkc_2015_1_25

2. Желік М.Б. Прийняття пропозиції, обіцянки або одержання неправомірної вигоди: кримінально-правова характеристика. Львів, 2018. 20 с.

3. Осадчий B.I. Проблеми кримінально-правового захисту правоохоронної діяльності / Національна академія внутрішніх справ України. Київ, 2004. С. 367-402

4. Ризак Я.В. Кримінальна відповідальність за підкуп службової особи юридичної особи приватного права/ Ген. прокуратура України, Нац. акад. прокуратури України. Київ, 2014. 20 с.

5. Светлов А.Я. Ответственность за должностные преступления. Київ : Наукова думка, 1978. 303 с.

Троченко О. В., здобувач ступеня доктора філософії Харківського національного педагогічного університету імені Г. С. Сковороди 